\title{
Effect of yeast vinasse on the growth of paspalum turf-grass under compost application in sandy soils
}

\author{
Asmaa M. Taha \\ Antoniadis Research Branch Alexandria, Ornamental Plants Research and Landscape Gardening Department, \\ Horticulture Research Institute, ARC, Egypt.
}

Received on: $2 / 11 / 2020$
Accepted on: 26/11/2020

\begin{abstract}
This study was done at Antoniades Research Branch, Horticulture Research Institute, A.R.C. Alexandria, Egypt during the two successive seasons of 2018 and 2019 to study the effects of yeast vinasse "Nutripotasse" as organic liquid fertilizer source and best time for its addition along the growth period under application of compost as organic manure on the vegetative growth, root characteristics and chemical analysis of Paspalum vaginatum plant, Sods of Paspalum turf-grass were planted in a plastic box $(40 \times 30 \times 15 \mathrm{~cm})$ filled with sandy soil, the compost treatments were $(0.0$ and $150 \mathrm{~g} /$ planting box). It was added to the surface of the soil before planting the sods. Five concentrations of diluted vinasse 0.0,2,4,6 and $8 \%$ were prepared and applied as a foliar application. The treatments started on the $1^{\text {st }}$ of April in both seasons and repeated five times four weeks interval. The cut was done after three weeks from vinasse treatment. The results showed the application of compost at $150 \mathrm{~g}$ / box resulted in the highest significant increases in plant height, stolen length, rhizome length, root characteristics, vegetative growth dry weight, chlorophyll a, potassium and nitrogen content. Moreover, applying vinasse at any concentration with or without compost treatment resulted in significant increase at any time of growing period in all studied parameters and the highest increase in these parameters was obtained after applying vinasse at $6 \%$.
\end{abstract}

KEYWORDS: Paspalum vaginatum, Yeast vinasse, Compost.

\section{INTRODUCTION}

Seashore paspalum (Paspalum vaginatum) is a warm-season perennial grass belongs to family: Poaceae, subfamily: Panicoideae which is suitable for growing in moist and salt affected soils. (Duncan and Carrow. 2000). It has many morphological characteristics to make it an illegible turfgrass such as good density, dark green color and an intermediate to fine leaf texture. Moreover, it has two kind of stems stolon and rhizomes (Raymer et al., 2008).

There is a need to decrease the cost of plant fertilization and increase the value of some organic residues. (Prado et al., 2013). An organic fertilizer refers to a soil amendment derived from natural sources that includes at least the minimum percentages of nitrogen, phosphate and potash (Louisa and Taguiling, 2013). The word compost points to an organic input or soil amendment that is applied to amend chemical and physical properties of the soil (Tennakoon and Bandara, 2003). Compost is a soil amendment produced through the metabolism of an organic substrate by aerobic (oxygen-requiring) microbes under controlled conditions.
Vinasse is a by-product from fermentation of molasses to produce some productions like yeasts, alcohol, citric acid or other substances. It is an aqueous effluent of the distillation unit of these industries and produced by large quantities. It is largely composed of water, organic matter, and mineral elements. Throw vinasse into the soil or running water cause environmental damage. Soil supplement with vinasse wastes caused a significant decrease in soil $\mathrm{pH}$ and significant increases in soil available $\mathrm{P}$, total $\mathrm{N}$, and total organic carbon (Gemtose et al., 1999).

Madejon et al., (2001) mentioned that, direct implantation of concentrated vinasse on agricultural lands may lead to economic and environmental problems due to high salinity. Tejada and Gonzalez (2006) mentioned that, regardless of the nutrient supply by the vinasse under dry land conditions, it may negatively effect on soil structure, nutrient uptake and crop yield and quality because of its high concentration of monovalent cations, such as $\mathrm{Na}$ and fulvic acids. Several studies were done to find alternative economic uses of this reduce such as, Mo 
et al., (2009) found that treating sugar cane with vinasse caused increment in its productivity and sucrose yields, Madejon et al., (2001) compared the yields of beets and maize after treatments with an organic compound based on vinasse or a mineral fertilizer and found that crop production was similar in both treatments indicating that the utilization of vinasse is a viable alternative for mineral fertilizers.

The experiment was established to study the possibility of using diluted yeast vinasse to replace the fertilization of potassium and partially replace fertilization with nitrogen due to its content of high level of organic matter, potassium, calcium and moderate amount of nitrogen and best time for its addition along the growth period under application of compost as organic manure on the vegetative growth, root characteristics and chemical analysis of Paspalum vaginatum plant.

Table 1. Analyses of the used soil.

\begin{tabular}{cllllll}
\hline $\begin{array}{c}\text { Mechanical } \\
\text { properties }\end{array}$ & Clay & Silt & & Sand & \\
\cline { 2 - 7 } $\begin{array}{c}\text { Chemical } \\
\text { properties }\end{array}$ & PH & Ec $(\mathbf{d s} / \mathbf{m})$ & $\begin{array}{l}\text { Organic } \\
\text { Matter } \\
(\boldsymbol{\%})\end{array}$ & $\begin{array}{l}\text { Total } \\
\text { Nitrogen } \\
(\boldsymbol{\%})\end{array}$ & $\begin{array}{l}\text { Available } \\
\text { Phosphorus } \\
(\mathbf{p p m})\end{array}$ & $\begin{array}{l}\text { Potassium } \\
(\mathbf{m g} / \mathbf{1 0 0 0 g})\end{array}$ \\
\cline { 2 - 7 } & 7.6 & 1.62 & 0.43 & 0.01 & 6.01 & 1.40 \\
\hline
\end{tabular}

\subsection{Treatments}

2.2.1. Yeast vinasse:

Liquid vinasse was obtained from a factory of yeast. The analysis of the used yeast vinasse is demonstrated in Table (2). Five concentrations of Table 2. Analysis of the used yeast vinasse.

\begin{tabular}{ccccccc}
\hline $\begin{array}{c}\text { Main elements } \\
\mathbf{K g ~} / \mathbf{m}^{3}\end{array}$ & $\begin{array}{c}\text { Organic Matter } \\
(\mathbf{O M})\end{array}$ & $\begin{array}{c}\text { Organic Nitrogen } \\
(\mathbf{N})\end{array}$ & $\begin{array}{c}\text { Potassium } \\
\left(\mathbf{K}_{\mathbf{2}} \mathbf{O}\right)\end{array}$ & $\begin{array}{c}\text { Calcium } \\
(\mathbf{C a O})\end{array}$ & $\begin{array}{c}\text { Magnesium } \\
(\mathbf{M g O})\end{array}$ & \\
\cline { 2 - 7 } $\begin{array}{c}\text { Trace elements } \\
\mathbf{g} / \mathbf{m}^{3}\end{array}$ & 30 & 2.5 & 8 & 1 & 0.5 & \\
& $\begin{array}{c}\text { Iron } \\
(\mathbf{F e})\end{array}$ & $\begin{array}{c}\text { Manganese } \\
(\mathbf{M n})\end{array}$ & $\begin{array}{c}\mathbf{Z i n c} \\
(\mathbf{Z n})\end{array}$ & $\begin{array}{c}\text { Boron } \\
(\mathbf{B})\end{array}$ & $\begin{array}{c}\mathbf{C o p p e r} \\
(\mathbf{C u})\end{array}$ & $\begin{array}{c}\text { Molybdenum } \\
(\mathbf{M o})\end{array}$ \\
\cline { 2 - 7 } & 34 & 7.8 & 6 & 0.7 & 0.5 & 1.5 \\
\hline & $\mathbf{p H}$ & & & $\mathbf{E c}(\mathbf{d s} / \mathbf{m})$ & \\
\hline
\end{tabular}

\subsubsection{Compost:}

Commercial compost was used in this study. The compost treatments were 0.0 and $150 \mathrm{~g} /$ planting box. It was added to the surface of the soil at $150 \mathrm{~g} /$ box before planting the sods. The analysis of the used compost is presented in Table (3).

\subsubsection{Time of cut:}

The turf was cut handily by very sharp stainless-steel cutter leaving stubble with 1 inch long. The cut was done after three weeks from vinasse treatment. Five cuts were done along the experiment period. The $1^{\text {st }}$ cut was done at $21^{\text {st }}$ of April , $2^{\text {nd }}$ cut was done at $21^{\text {st }}$ of May , $3^{\text {rd }}$ cut was done at $21^{\text {st }}$ of June , $4^{\text {th }}$ cut was done at $21^{\text {st }}$ of July and $5^{\text {th }}$ cut was

\section{MATERIAL AND METHODS}

This experiment was performed during the two successive seasons 2018 and 2019 at Antoniades Research Branch, Horticultural Research Institute, A.R.C. Alexandria, Egypt.

\subsection{Plant material:}

Sods of Paspalum turf-grass (Paspalum vaginatum Swartz) were obtained from a well-known commercial nursery and planted on the $22^{\text {nd }}$ and $24^{\text {th }}$ of March in the two seasons, respectively. The sods were planting in plastic box $(40 \times 30 \times 15 \mathrm{~cm})$ filled with sandy soil Table (1) indicate its analysis Carter and Gregorich (2008). The sods were irrigated once a day with a tap water during the first 2 weeks after planting, then. The irrigation was applied according to the climatic conditions. The sods were fertilized by added ammonium nitrate $(33.5 \% \mathrm{~N})$ applied as dressing on soil surface at $3 \mathrm{~g} / \mathrm{L}$ after each cut. diluted vinasse $0.0,2,4,6$ and $8 \%$ were prepared and applied as a foliar application by hand sprayer till the run off point. The treatments started on the $1^{\text {st }}$ of April in both seasons and repeated five times four weeks interval.

done at $21^{\text {st }}$ of August in both seasons. The average of temperature during the time of cut is presented in Table (4).

2.3. The following data were recorded in both two seasons:

2.3.1. Data recorded after each cut :

a. Vegetative growth dry weight (g/box)

b. Chemical analysis: Chlorophyll a and b content $(\mathrm{mg} / 100 \mathrm{~g}$ leaves fresh weight) was determined according to Moran (1982), Nitrogen content $(\%)$ and Potassium content (\%) were determined according to Nielsen (2010). 
Asmaa M. Taha., 2020

Table 3. Analysis of the used compost.

\begin{tabular}{|c|c|c|c|c|c|c|}
\hline \multirow[t]{2}{*}{$\begin{array}{c}\text { Main } \\
\text { elements }\end{array}$} & $\begin{array}{c}\text { Organic } \\
\text { Matter } \\
(\%)\end{array}$ & $\begin{array}{c}\text { Organic } \\
\text { carbon } \\
(\%)\end{array}$ & $\begin{array}{c}\mathrm{C} / \mathrm{N} \\
\text { ratio }\end{array}$ & $\begin{array}{c}\text { Total } \\
\text { Nitrogen }(\mathbf{N}) \\
(\%)\end{array}$ & $\begin{array}{c}\text { Total } \\
\text { Phosphorus (P) } \\
(\%)\end{array}$ & $\begin{array}{c}\text { Potassium }(\mathbf{K}) \\
(\%)\end{array}$ \\
\hline & 52.8 & 30.6 & 18.1 & 1.7 & 1.47 & 3.43 \\
\hline \multirow{4}{*}{$\begin{array}{c}\text { Trace } \\
\text { elements } \\
(p p m) \\
\end{array}$} & \multicolumn{2}{|c|}{$\begin{array}{c}\text { Iron } \\
(\text { Fe) }\end{array}$} & \multicolumn{2}{|c|}{$\begin{array}{l}\text { Manganese } \\
\text { (Mn) }\end{array}$} & $\begin{array}{l}\text { Zinc } \\
\text { (Zn) }\end{array}$ & $\begin{array}{c}\text { Copper } \\
(\mathbf{C u})\end{array}$ \\
\hline & \multicolumn{2}{|c|}{990} & \multicolumn{2}{|c|}{370} & 330 & 200 \\
\hline & \multicolumn{2}{|c|}{$\begin{array}{l}\text { Weight of full } \\
\text { dried } \mathbf{m}^{3} \\
\left(\mathrm{~kg} / \mathrm{m}^{3}\right)\end{array}$} & \multicolumn{2}{|c|}{$\begin{array}{c}\text { Moisture } \\
\%\end{array}$} & pH & $\begin{array}{c}\text { Ec } \\
(\mathbf{d s} / \mathbf{m})\end{array}$ \\
\hline & \multicolumn{2}{|c|}{$400-500$} & \multicolumn{2}{|c|}{$20-25$} & 7.7 & 4.33 \\
\hline
\end{tabular}

Table 4. The average temperature in Alexandria throughout the growing period of paspalum grass during the two seasons 2018-2019.

\begin{tabular}{ccc}
\hline \multirow{2}{*}{ Months } & \multicolumn{3}{c}{ Average temperature ${ }^{\circ} \mathbf{C}$} \\
\cline { 2 - 3 } & $\mathbf{2 0 1 8}$ & $\mathbf{2 0 1 9}$ \\
\hline April & 21 & 18 \\
May & 24 & 23 \\
June & 27 & 27 \\
July & 28 & 28 \\
August & 28 & 28 \\
\hline
\end{tabular}

\subsubsection{Data recorded at the end of the experiment:}

After the $5^{\text {th }}$ cut the experiment was terminated and the following data was recorded: plant height $(\mathrm{cm})$, rhizome length $(\mathrm{cm})$, stolon length $(\mathrm{cm})$, root length $(\mathrm{cm})$, main root diameter $(\mathrm{mm})$, root volume $\left(\mathrm{cm}^{3}\right)$ and root dry weight $(\mathrm{g})$.

\subsection{Statistical analysis:}

2.4.1. For the data recorded after each cut.

The experiment layout was designed provide one factor (the concentration and materials used), in complete randomized block design in factorial experiment (RCBD) with split in time design in three replicates which content 50 unit/ replicate. The main plot represented the time of cut (5 cuts). The Sub- plot represented interaction between vinasse and compost.

\subsubsection{For the data recorded at the end of the experiment.}

The experiment layout was designed provide complete randomized block design in factorial experiment (RCBD). Which contained three replicates which content 10 unit/ replicate. Five concentration of vinasse with or without combination with compost.

The means of the individual factors and their interactions were compared by L.S.D test at $5 \%$ level of probability according to Snedecor and Cochran (1989).

\section{RESULTS}

3.1. Data recorded after each cut.

3.1.1. Vegetative growth dry weight (g/box) :

Data in Table (5) showed that, there was a significant different for the interaction between compost treatment, vinasse concentrations and time of cut. Generally, the dry weight of vegetative growth in both seasons were increased by increasing the rate of vinasse along the time of the experiment .The highest increase in vegetative growth dry weight was observed after application vinasse at $6 \%$ and $8 \%$ and compost at $150 \mathrm{~g}$ in fourth time of cut in the first season while the second one the highest increase was obtained after application of vinasse at $6 \%$ with or without compost at $150 \mathrm{~g}$ in fourth and fifth time of cut.

Table (6) showed that compost addition to paspalum at $150 \mathrm{~g}$ gave the maximum increase in vegetative growth dry weight during the two seasons. Furthermore, using vinasse at any concentration with or without compost gave the highest average for vegetative growth dry weight during the two seasons compared with the control treatment. The highest increase in dry weight was recorded after using vinasse at $6 \%$ which recorded 104.33 and $93.37 \mathrm{~g} / \mathrm{box}$ in both seasons. Also, Table (6) showed that the fourth time of cut $\left(21^{\text {st }}\right.$ of July) gave the heaviest vegetative growth dry weight in both seasons. Which were 111.44 and $89.72 \mathrm{~g} / \mathrm{box}$. 
Table 5. Means of vegetative growth dry weight (g) of Paspalum vaginatum as influenced by the interaction between Compost application $(\mathrm{C})$, different concentrations of Vinasse $(\mathrm{V})$ and time of cut $(T)$ during the two successive seasons of 2018 and 2019.

\begin{tabular}{|c|c|c|c|c|c|c|c|c|c|c|c|}
\hline \multirow{4}{*}{$\begin{array}{c}\text { Compost } \\
\text { (g) }\end{array}$} & \multirow{4}{*}{$\begin{array}{c}\text { Vinasse } \\
(\%)\end{array}$} & \multicolumn{10}{|c|}{ Vegetative growth dry weight (g/box) } \\
\hline & & \multicolumn{5}{|c|}{2018} & \multicolumn{5}{|c|}{2019} \\
\hline & & \multicolumn{5}{|c|}{ Time of cut } & \multicolumn{5}{|c|}{ Time of cut } \\
\hline & & $1^{\text {th }}$ & $2^{\text {nd }}$ & $3^{\text {rd }}$ & $4^{\text {th }}$ & $5^{\text {th }}$ & $\mathbf{1}^{\text {st }}$ & $2^{\text {nd }}$ & $3^{\text {rd }}$ & $4^{\text {th }}$ & $5^{\text {th }}$ \\
\hline \multirow{6}{*}{$\mathbf{0 . 0}$} & $\mathbf{0}$ & 32.89 & 26.66 & 22.96 & 66.66 & 75.85 & 36.59 & 11.71 & 41.33 & 58.96 & 30.37 \\
\hline & 2 & 39.55 & 77.19 & 65.93 & 99.56 & 111.11 & 40.89 & 36.74 & 64.30 & 70.37 & 59.11 \\
\hline & 4 & 53.93 & 91.11 & 96.89 & 101.78 & 101.78 & 48.59 & 65.63 & 71.26 & 94.22 & 61.93 \\
\hline & 6 & 53.78 & 106.52 & 118.96 & 114.96 & 106.52 & 58.82 & 66.67 & 74.52 & 116.59 & 120.30 \\
\hline & 8 & 44.30 & 73.78 & 109.19 & 111.11 & 99.41 & 45.63 & 65.78 & 72.00 & 98.22 & 92.44 \\
\hline & $\mathbf{0}$ & 39.85 & 36.30 & 63.11 & 85.63 & 88.29 & 48.15 & 26.07 & 50.67 & 74.96 & 57.48 \\
\hline \multirow{4}{*}{150} & 2 & 42.07 & 72.00 & 74.96 & 103.85 & 90.81 & 49.33 & 59.85 & 65.33 & 80.74 & 68.89 \\
\hline & 4 & 43.26 & 86.22 & 92.00 & 130.96 & 107.85 & 51.56 & 79.85 & 87.56 & 87.85 & 79.41 \\
\hline & 6 & 59.85 & 105.04 & 108.74 & 153.34 & 115.56 & 78.67 & 104.44 & 88.59 & 116.59 & 120.74 \\
\hline & 8 & 32.44 & 70.67 & 105.48 & 146.52 & 63.41 & 61.63 & 89.48 & 74.52 & 98.66 & 81.18 \\
\hline \multicolumn{2}{|c|}{$\begin{array}{c}\text { L.S.D at } 0.05 \\
\text { C } * V^{*} T\end{array}$} & \multicolumn{5}{|c|}{9.92} & \multicolumn{5}{|c|}{10.21} \\
\hline
\end{tabular}

Table 6. Means of dry weight $(\mathrm{g})$, chlorophyll a $(\mathrm{mg} / \mathbf{1 0 0 g})$, chlorophyll b (mg/100g), potassium (\%) and nitrogen $(\%)$ of Paspalum vaginatum as influenced by time of cut, compost application (C) and Vinasse concentrations $(V)$ during the two successive seasons of 2018 and 2019.

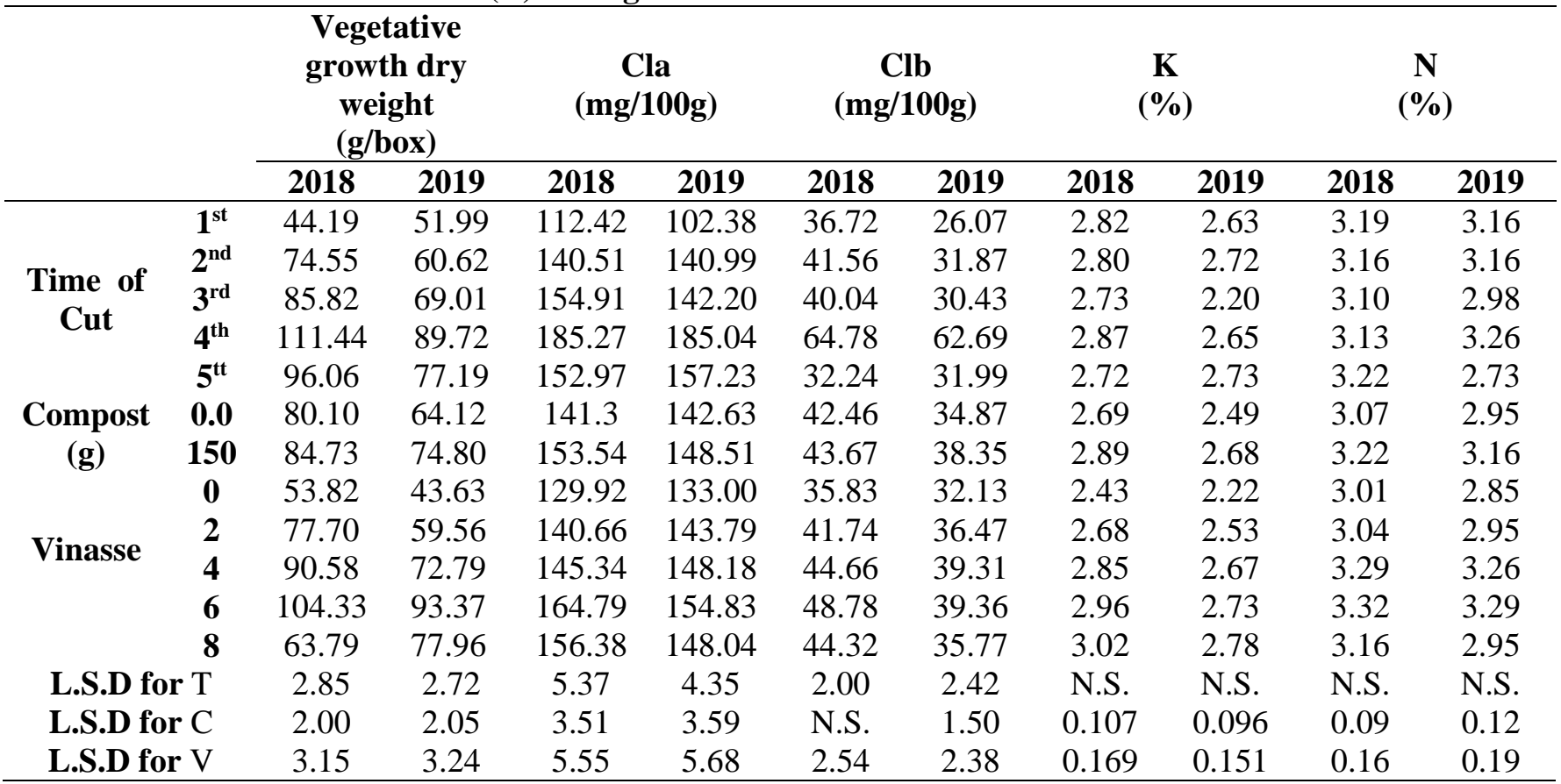

\subsubsection{Chemical analysis}

3.1.2.1. Chlorophyll a and $b(\mathbf{m g} / \mathbf{1 0 0 g})$

Table (6) cleared that, applying of compost at $150 \mathrm{~g}$ caused increment in chlorophyll $\mathrm{a}$ and $\mathrm{b}$ content which recorded (153.54 and 148.51 for chlorophyll a) and (43.67 and 38.35 for chlorophyll b) in both seasons. The values of chlorophyll $a$ and $b$ in leaves were increased by increasing the rate of vinasse compared to control plant in both seasons, Also, Table
(6) showed that the fourth time of cut gave the highest value of chlorophyll $a$ and $b$ in both seasons.

Table (7) showed that, the highest chlorophyll a content 197.19 and $197.55 \mathrm{mg} / 100 \mathrm{~g}$ fresh weight and chlorophyll b content (78.26 and $67.46 \mathrm{mg} / 100 \mathrm{~g}$ fresh weight) in both seasons, respectively was recorded in case of treatment $6 \%$ vinasse in fourth time of cut. 
Table 7. Means of chlorophyll a $(\mathrm{mg} / \mathbf{1 0 0 g})$ and chlorophyll b $(\mathrm{mg} / \mathbf{1 0 0 g})$ of Paspalum vaginatum as influenced by the interaction between vinasse concentrations $(V)$ and time of cut $(T)$ during the two successive seasons of 2018 and 2019.

\begin{tabular}{|c|c|c|c|c|c|}
\hline \multirow{2}{*}{$\begin{array}{c}\text { Vinasse } \\
(\%)\end{array}$} & \multirow{2}{*}{$\begin{array}{l}\text { Time } \\
\text { of cut }\end{array}$} & \multicolumn{2}{|c|}{$\mathrm{Cl}$ a $(\mathrm{mg} / \mathbf{1 0 0 g})$} & \multicolumn{2}{|c|}{$\mathrm{Cl} \mathrm{b}(\mathrm{mg} / \mathbf{1 0 0 g})$} \\
\hline & & 2018 & 2019 & 2018 & 2019 \\
\hline \multirow{5}{*}{ 0 } & $\mathbf{1}^{\text {st }}$ & 88.62 & 98.97 & 33.23 & 23.33 \\
\hline & $2^{\text {nd }}$ & 130.29 & 128.16 & 34.45 & 28.52 \\
\hline & $3^{\text {rd }}$ & 128.29 & 118.09 & 34.79 & 25.32 \\
\hline & $4^{\text {th }}$ & 170.96 & 172.21 & 51.25 & 53.88 \\
\hline & $5^{\text {th }}$ & 131.43 & 147.58 & 25.45 & 29.58 \\
\hline \multirow{5}{*}{2} & $1^{\text {st }}$ & 98.20 & 102.11 & 34.70 & 25.60 \\
\hline & $2^{\text {nd }}$ & 134.36 & 141.69 & 39.89 & 32.71 \\
\hline & $3^{\text {rd }}$ & 137.57 & 130.53 & 38.76 & 28.21 \\
\hline & $4^{\text {th }}$ & 186.56 & 186.53 & 65.42 & 63.83 \\
\hline & $5^{\text {th }}$ & 146.61 & 158.11 & 29.95 & 32.00 \\
\hline \multirow{5}{*}{4} & $1^{\text {st }}$ & 102.41 & 102.28 & 38.59 & 26.90 \\
\hline & $2^{\text {nd }}$ & 139.38 & 144.17 & 42.33 & 35.25 \\
\hline & $3^{\text {rd }}$ & 139.03 & 143.95 & 39.70 & 31.79 \\
\hline & $4^{\text {th }}$ & 189.23 & 190.79 & 68.52 & 68.43 \\
\hline & $5^{\text {th }}$ & 156.66 & 159.72 & 34.18 & 34.20 \\
\hline \multirow{5}{*}{6} & $1^{\text {st }}$ & 152.32 & 108.18 & 41.00 & 29.15 \\
\hline & $2^{\text {nd }}$ & 148.41 & 146.04 & 45.08 & 34.31 \\
\hline & $3^{\text {rd }}$ & 160.39 & 158.15 & 43.18 & 33.50 \\
\hline & $4^{\text {th }}$ & 197.19 & 197.55 & 78.26 & 67.46 \\
\hline & $5^{\text {th }}$ & 165.63 & 164.25 & 36.36 & 32.38 \\
\hline \multirow{5}{*}{8} & $1^{\text {st }}$ & 120.54 & 100.38 & 36.10 & 25.35 \\
\hline & $2^{\text {nd }}$ & 150.13 & 144.93 & 46.03 & 28.53 \\
\hline & $3^{\text {rd }}$ & 164.26 & 160.30 & 43.77 & 33.33 \\
\hline & $4^{\text {th }}$ & 182.43 & 178.10 & 60.46 & 59.86 \\
\hline & $5^{\text {th }}$ & 164.53 & 156.50 & 35.26 & 31.78 \\
\hline \multicolumn{2}{|c|}{ L.S.D for $T^{*} V$} & 14.85 & 15.59 & 6.62 & N.S. \\
\hline
\end{tabular}

Table(8) indicated that, using compost at $150 \mathrm{~g}$ fresh weight) and chlorophyll a which was (66.86 and at the fourth time of cut caused the highest values of $63.94 \mathrm{mg} / 100 \mathrm{~g}$ fresh weight) in both seasons. chlorophyll a which was (188.73 and $188.74 \mathrm{mg} / 100 \mathrm{~g}$

Table 8. Means of chlorophyll a (mg/100g), chlorophyll b (mg/100g), potassium (\%) and nitrogen (\%) of Paspalum vaginatum as influenced by the interaction between Compost application $(C)$ and time of cut $(T)$ during the two successive seasons of 2018 and 2019.

\begin{tabular}{|c|c|c|c|c|c|c|c|c|c|}
\hline \multirow{2}{*}{$\begin{array}{c}\text { Compost } \\
\text { (g) }\end{array}$} & \multirow{2}{*}{$\begin{array}{l}\text { Time } \\
\text { of cut }\end{array}$} & \multicolumn{2}{|c|}{ Cl a (mg/100g) } & \multicolumn{2}{|c|}{ Cl b (mg/100g) } & \multicolumn{2}{|c|}{ K (\%) } & \multicolumn{2}{|c|}{$\mathbf{N}(\%)$} \\
\hline & & 2018 & 2019 & 2018 & 2019 & 2018 & 2019 & 2018 & 2019 \\
\hline \multirow{5}{*}{0.0} & $\mathbf{1}^{\text {st }}$ & 108.23 & 101.7 & 30.94 & 23.52 & 2.71 & 2.58 & 3.19 & 3.16 \\
\hline & $2^{\text {nd }}$ & 133.82 & 143.3 & 36.53 & 30.20 & 2.66 & 2.71 & 3.01 & 2.98 \\
\hline & $3^{\text {rd }}$ & 137.34 & 136.61 & 37.95 & 30.69 & 2.52 & 2.19 & 2.91 & 2.70 \\
\hline & $4^{\text {th }}$ & 181.82 & 181.34 & 62.36 & 61.45 & 2.81 & 2.51 & 3.07 & 3.16 \\
\hline & $5^{\text {th }}$ & 145.27 & 150.21 & 39.00 & 32.47 & 2.74 & 2.45 & 3.19 & 2.73 \\
\hline \multirow{5}{*}{150} & $1^{\text {st }}$ & 116.61 & 103.06 & 33.47 & 28.39 & 2.93 & 2.68 & 3.19 & 3.16 \\
\hline & $2^{\text {nd }}$ & 147.2 & 138.69 & 36.92 & 28.51 & 2.96 & 2.74 & 3.35 & 3.32 \\
\hline & $3^{\text {rd }}$ & 154.48 & 147.80 & 41.49 & 33.77 & 2.94 & 2.21 & 3.29 & 3.26 \\
\hline & $4^{\text {th }}$ & 188.73 & 188.74 & 66.86 & 63.94 & 2.94 & 2.79 & 3.16 & 3.32 \\
\hline & $5^{\text {th }}$ & 160.67 & 164.25 & 44.49 & 33.03 & 2.69 & 3.00 & 3.22 & 2.76 \\
\hline \multicolumn{2}{|c|}{ L.S.D for $T^{*} \mathbf{C}$} & N.S & 9.86 & 3.50 & N.S. & N.S & 0.42 & 0.28 & 0.50 \\
\hline
\end{tabular}




\subsubsection{Potassium content and Nitrogen content $(\%)$}

Data in Table (6) showed that time of cut has no significant effect on nitrogen and potassium content. Also Table (6) cleared that addition of compost at $150 \mathrm{gm}$ caused a significant increase in the percentage of both of potassium and nitrogen content which recorded (2.89 and 2.68\%) for potassium and (3.22 and $3.16 \%$ ) for nitrogen in the first and second season, respectively as compared to control plant. Also, all concentrations of vinasse have a significant effect on both of potassium and nitrogen percentage and the maximum values for potassium percentage were obtained after the application of vinasse at $8 \%$ which recorded (3.02 and $2.78 \%$ ) in the first and second season, respectively. While the highest values for nitrogen content were obtained after applying of vinasse at $6 \%$ which recorded (3.32 and $3.29 \%)$ in the first and second season, respectively.

Table 9. Means of potassium (\%) and nitrogen (\%) of Paspalum vaginatum as influenced by the interaction between compost application $(C)$ and different concentrations of vinasse $(V)$ during the two successive seasons of 2018 and 2019.

\begin{tabular}{|c|c|c|c|c|c|}
\hline \multirow{2}{*}{$\begin{array}{c}\text { Compost } \\
\text { (g) }\end{array}$} & \multirow{2}{*}{$\begin{array}{c}\text { Vinasse } \\
(\%)\end{array}$} & \multicolumn{2}{|c|}{ K $(\%)$} & \multicolumn{2}{|c|}{$\mathbf{N}(\%)$} \\
\hline & & 2018 & 2019 & 2018 & 2019 \\
\hline \multirow{5}{*}{0.0} & 0 & 2.31 & 2.06 & 2.79 & 2.70 \\
\hline & 2 & 2.59 & 2.47 & 2.95 & 2.82 \\
\hline & 4 & 2.72 & 2.55 & 3.32 & 3.26 \\
\hline & 6 & 2.86 & 2.65 & 3.32 & 3.29 \\
\hline & 8 & 2.95 & 2.73 & 3.01 & 2.67 \\
\hline \multirow{5}{*}{150} & $\mathbf{0}$ & 2.54 & 2.39 & 3.16 & 3.01 \\
\hline & 2 & 2.77 & 2.59 & 3.19 & 3.10 \\
\hline & 4 & 2.99 & 2.78 & 3.26 & 3.26 \\
\hline & 6 & 3.05 & 2.82 & 3.32 & 3.29 \\
\hline & 8 & 3.09 & 2.83 & 3.29 & 3.19 \\
\hline L.S.I & $\mathrm{C}^{*} \mathrm{~V}$ & N.S. & 0.21 & 0.21 & 0.26 \\
\hline
\end{tabular}

3.2. Data recorded at the end of the experiment.

Data in Table (10) showed that there was no significant different for the interaction between the application of compost and vinasse concentrations for plant height, rhizome length and stolon length.

Also Table (10) cleared that for plant height addition of compost at $150 \mathrm{~g}$ caused the highest significant increase in plant height which recorded $(11.05$ and $12.33 \mathrm{~cm})$ in the first and second season, respectively as compared to control plant witch recorded $(10.07$ and $10.88 \mathrm{~cm})$ in the same seasons. Also, all concentrations of vinasse have a significant effect of plant height and the tallest plant height was obtained after application of vinasse at $6 \%$ which recorded $(13.33$ and $15.42 \mathrm{~cm})$ in the first and second season, respectively.
Moreover, data in Table (8) indicated that there was a significant different for the interaction between times of cuts and compost application. All treatments caused increase in nitrogen and potassium percentage. The lowest nitrogen and potassium percentage were obtained at the interaction between the third time of cut ( $21^{\text {st }}$ of June) and 0.0 compost.

For the interaction between compost and vinasse treatments. Table (9), cleared that all treatments caused increase in potassium and nitrogen percentage compared to control plants. Using $150 \mathrm{~g}$ with $8 \%$ vinasse caused the highest percentage of potassium percentage which recorded (3.09 and 2.83 $\%)$ in both seasons. Moreover, the highest nitrogen content (3.32 and $3.29 \%)$ in the first and second season, respectively was obtained by using $150 \mathrm{~g}$ compost and $6 \%$ vinasse.
For rhizome length, Table (10) showed that the tallest significant rhizome length was obtained after adding compost at $150 \mathrm{~g}$ which was (12.87 and $13.13 \mathrm{~cm}$ ) in first and second season, respectively. On the other hand, the vinasse amendment as $6 \%$ caused significant increase in rhizome length in both season which recorded $(15.46$ and $16.25 \mathrm{~cm})$.

Data in Table (10) indicated that using compost at $150 \mathrm{~g}$ resulted in a significant increase in stolon length which recorded $(1.24$ and $1.35 \mathrm{~cm})$ in the first and second season, respectively. For the effect of different vinasse concentrations Table (10) cleared that using vinasse at $4 \%$ and $6 \%$ caused the highest significant stolon length. The tallest length (1.38 and $1.47 \mathrm{~cm}$ ) was recorded after using $6 \%$ vinasse in the first and second season, respectively. 
Asmaa M. Taha., 2020

Table 10. Means of plant height $(\mathrm{cm})$, rhizome length $(\mathrm{cm})$ and stolon length $(\mathrm{cm})$ of Paspalum vaginatum as influenced by the interaction between compost application $(C)$ and different concentrations of vinasse $(V)$ during the two successive seasons of 2018 and 2019.

\begin{tabular}{cccccccc}
\hline \multirow{2}{*}{$\begin{array}{c}\text { Compost } \\
(\mathbf{g})\end{array}$} & $\begin{array}{c}\text { Vinasse } \\
(\mathbf{\%})\end{array}$ & \multicolumn{2}{c}{ Plant height $(\mathbf{c m})$} & \multicolumn{2}{c}{ Rhizome length(cm) } & \multicolumn{2}{c}{ Stolon length(cm) } \\
\cline { 3 - 7 } & $\mathbf{2 0 1 8}$ & $\mathbf{2 0 1 9}$ & $\mathbf{2 0 1 8}$ & $\mathbf{2 0 1 9}$ & $\mathbf{2 0 1 8}$ & $\mathbf{2 0 1 9}$ \\
\hline $\mathbf{0 . 0}$ & $\mathbf{2}$ & 9.17 & 6.75 & 8.25 & 7.88 & 0.73 & 0.83 \\
& $\mathbf{4}$ & 10.33 & 11.83 & 12.50 & 12.50 & 1.07 & 1.00 \\
& $\mathbf{6}$ & 12.50 & 14.00 & 15.08 & 15.83 & 1.23 & 1.07 \\
Mean & $\mathbf{8}$ & 12.33 & 11.67 & 10.00 & 10.67 & 1.13 & 1.10 \\
& & 10.07 & 10.88 & 11.70 & 11.98 & 1.09 & 1.05 \\
& $\mathbf{0}$ & 7.00 & 9.00 & 10.56 & 9.56 & 0.93 & 1.03 \\
$\mathbf{1 5 0}$ & $\mathbf{2}$ & 9.83 & 10.00 & 14.00 & 13.67 & 1.20 & 1.37 \\
& $\mathbf{4}$ & 10.92 & 13.00 & 14.50 & 14.00 & 1.40 & 1.50 \\
Mean & $\mathbf{6}$ & 14.17 & 16.83 & 15.83 & 16.67 & 1.50 & 1.67 \\
Mean & $\mathbf{8}$ & 13.33 & 12.83 & 9.44 & 11.78 & 1.17 & 1.20 \\
of & & 11.05 & 12.33 & 12.87 & 13.13 & 1.24 & 1.35 \\
vinasse & $\mathbf{0}$ & 6.50 & 7.88 & 9.40 & 8.72 & 0.83 & 0.93 \\
$(\boldsymbol{\%})$ & $\mathbf{2}$ & 9.50 & 10.08 & 13.25 & 13.08 & 1.13 & 1.18 \\
& $\mathbf{4}$ & 10.63 & 12.42 & 13.58 & 13.50 & 1.32 & 1.28 \\
L.S.D for & $\mathbf{6}$ & 13.33 & 15.42 & 15.46 & 16.25 & 1.38 & 1.47 \\
& $\mathbf{8}$ & 12.83 & 12.25 & 9.72 & 11.22 & 1.15 & 1.15 \\
& $\mathbf{C}$ & 0.78 & 0.71 & 1.05 & 0.86 & 0.13 & 0.18 \\
& $\mathbf{V}$ & 1.24 & 1.12 & 1.66 & 1.36 & 0.20 & 0.28 \\
\end{tabular}

Data in Table (11) revealed that there was insignificant different for the interaction between the application of compost and vinasse concentrations for root length. Also, Table (11) revealed that, a highly significant effect on root length was observed after using compost at $150 \mathrm{~g}$ which recorded (16.43 and $17.80 \mathrm{~cm})$ in both seasons. Moreover, all concentrations of vinasse has a significant effect on root length compared to control plant. The highest root length were $(17.50$ and $20.17 \mathrm{~cm})$ in both seasons, which recorded in case of treatment $6 \%$ vinasse.

For main root diameter, regarding the effect of vinasse concentration alone or with compost concentration there was a significant increase in main root diameter compared to control plants in the first season. Table (11) cleared that vinasse at $4 \%$ or $6 \%$ have the same level of significant and the thickest diameter (2.64 and $2.66 \mathrm{~mm}$ ) was recorded after $6 \%$ of vinasse in two seasons. On the other hand, using $150 \mathrm{~g}$ of compost give the highest main root diameter which recorded (2.35 and $2.46 \mathrm{~mm}$ ) in both seasons, respectively.

Moreover, for root volume data in Table (11) indicated that there was a significant different for the interaction between application of compost and vinasse concentration. All treatments caused a significant increase compared to control plants except the treatment 0.0 compost and $8 \%$ vinasse concentration.

Table (11) cleared that using $150 \mathrm{~g}$ of compost caused a significant increase in root volume. Also, using vinasse at $6 \%$ resulted in the highest significant root volume in both seasons. Also, the highest root volume was obtained after application of compost at $150 \mathrm{~g}$ and $6 \%$ vinasse which recorded (10296.30 and $9333.33 \mathrm{~cm}^{3} /$ box $)$ in the first and second season, respectively.

Data in Table (11) showed that using of vinasse at $4 \%$ and $6 \%$ and compost at $150 \mathrm{~g}$ resulted in the highest significant increase in root dry weight. The heaviest dry weight was obtained after application of $6 \%$ vinasse with $150 \mathrm{~g}$ compost which recorded (5228.44 and $4967.41 \mathrm{~g} / \mathrm{box}$ ) in the first and second season respectively. Moreover, application of compost resulted in a significant increase of root dry weight which recorded (3824.15 and $3766.64 \mathrm{~g} / \mathrm{box}$ ) in the first and second season respectively. 
Scientific Journal of Agricultural Sciences 2 (2): 19-28, 2020

Table 11. Means of root length $(\mathrm{cm})$, main root diameter $(\mathrm{mm})$, root volume $\left(\mathrm{cm}^{3} / \mathrm{box}\right)$ and root dry weight (g/box) of Paspalum vaginatum as influenced by the interaction between Compost application (C) and different concentrations of Vinasse (V) during the two successive seasons of 2018 and 2019.

\begin{tabular}{|c|c|c|c|c|c|c|c|c|c|}
\hline \multirow{2}{*}{$\begin{array}{c}\text { Compost } \\
\text { (g) }\end{array}$} & \multirow{2}{*}{$\begin{array}{c}\text { Vinasse } \\
(\%)\end{array}$} & \multicolumn{2}{|c|}{$\begin{array}{l}\text { Root length } \\
(\mathrm{cm})\end{array}$} & \multicolumn{2}{|c|}{$\begin{array}{c}\text { Main root } \\
\text { diameter }(\mathbf{m m})\end{array}$} & \multicolumn{2}{|c|}{$\begin{array}{l}\text { Root volume } \\
\left(\mathrm{cm}^{3} / \mathrm{box}\right)\end{array}$} & \multicolumn{2}{|c|}{$\begin{array}{c}\text { Root dry weight } \\
\text { (g/box })\end{array}$} \\
\hline & & 2018 & 2019 & 2018 & 2019 & 2018 & 2019 & 2018 & 2019 \\
\hline \multirow{5}{*}{0.0} & $\mathbf{0}$ & 9.67 & 12.00 & 1.16 & 1.61 & 5777.78 & 5037.04 & 1907.41 & 1851.85 \\
\hline & 2 & 12.17 & 15.33 & 2.28 & 2.12 & 7629.63 & 5333.33 & 2184.74 & 2331.26 \\
\hline & 4 & 14.83 & 18.50 & 2.44 & 2.49 & 7703.70 & 6074.07 & 2733.63 & 2523.11 \\
\hline & 6 & 16.67 & 19.67 & 2.40 & 2.56 & 7851.85 & 6444.44 & 2883.26 & 2846.52 \\
\hline & 8 & 16.00 & 16.00 & 2.37 & 2.32 & 5555.56 & 5362.96 & 2166.67 & 2120.89 \\
\hline \multirow[t]{3}{*}{ Mean } & & 13.87 & 16.30 & 2.13 & 2.22 & 6903.70 & 5650.37 & 2375.14 & 2334.73 \\
\hline & $\mathbf{0}$ & 13.33 & 14.00 & 1.83 & 2.05 & 6740.74 & 6000.00 & 2214.67 & 2362.81 \\
\hline & 2 & 15.67 & 17.33 & 2.48 & 2.48 & 9111.11 & 8740.74 & 4396.44 & 4216.30 \\
\hline \multirow[t]{3}{*}{150} & 4 & 16.67 & 20.00 & 2.51 & 2.61 & 9925.93 & 8933.33 & 4981.19 & 4769.93 \\
\hline & 6 & 18.33 & 20.67 & 2.87 & 2.77 & 10296.3 & 9333.33 & 5228.44 & 4967.41 \\
\hline & 8 & 17.33 & 17.00 & 2.05 & 2.42 & 7777.78 & 5851.85 & 2300.00 & 2516.74 \\
\hline Mean & & 16.43 & 17.80 & 2.35 & 2.46 & 8770.37 & 7771.85 & 3824.15 & 3766.64 \\
\hline \multirow{5}{*}{$\begin{array}{c}\begin{array}{c}\text { Mean } \\
\text { of } \\
\text { vinasse } \\
(\%)\end{array} \\
\text { (\%) }\end{array}$} & $\mathbf{0}$ & 11.50 & 13.00 & 1.49 & 1.83 & 6259.26 & 5518.52 & 2061.04 & 2107.33 \\
\hline & 2 & 13.92 & 16.33 & 2.38 & 2.30 & 8370.37 & 7037.04 & 3290.59 & 3273.78 \\
\hline & 4 & 15.75 & 19.25 & 2.48 & 2.55 & 8814.81 & 7503.70 & 3857.41 & 3646.52 \\
\hline & 6 & 17.50 & 20.17 & 2.64 & 2.66 & 9074.07 & 7888.89 & 4055.85 & 3906.96 \\
\hline & 8 & 16.67 & 16.50 & 2.21 & 2.37 & 6666.67 & 5607.41 & 2233.33 & 2318.81 \\
\hline \multirow{3}{*}{ L.S.D for } & C. & 1.38 & 0.97 & 0.13 & 0.12 & 222.73 & 285.27 & 178.02 & 208.75 \\
\hline & V. & $2 . .13$ & 1.54 & 0.21 & 0.19 & 352.17 & 451.05 & 281.47 & 330.07 \\
\hline & C.XV. & N.S & N.S & 0.30 & N.S & 498.05 & 637.88 & 398.06 & 466.79 \\
\hline
\end{tabular}

4. Discussion

The increase in vegetative growth parameters, root growth parameters and chemical analysis of paspalum turf-grass after application of vinasse treatment may be due to the high content of potassium and moderate content of nitrogen (Table 2) which influence the soil properties and increase the nutrient uptake of plants. Also, nitrogen and potassium are responsible for many biochemical processes such as photosynthesis, respiration, protein and carbohydrates metabolism (Awaad et al., 2010). Potassium increases the ability of turf to overcome numerous stresses on turf by regulating of stomatal function, which enhances shoot water potential of the turf-grass plant Trenholm et al., (2001) Moreover, the analysis of yeast vinasse (Table 2) cleared that it has macro nutrient like Zinc and Molybdenum these elements are responsible on increasing growth and yield attributes Mahapatra et al., (2018) This results are in agreement with those obtained by (Komdorfer and Anderson, 1993) on sugarcane, wheat, pigeon pea and maize, Mahmoud et al., ( 2019) on spinach and barley and Biswas and Dutta (2019) on Solanum tuberosum.

For the effect of compost on the studied vegetative growth, root growth, chemical analysis parameters data showed that applying compost resulted in significant increase in these parameters. This increment may be due to addition organic manure in form of compost improves the soil fertility by their composition from macro and micro nutrients, amino acids, organic acid, sugar and organic matter Martínez et al., (2013).

Paspalum is a warm season grass which grow well (25- 30C) (Beard, 1982). So the decrease in growth on April may be attributed to the unsuitable temperature for growing paspalum in this month (Table 4).

For the interaction between applications of vinasse, adding compost and time of cut the positive effect of these interactions may be due to the ripple effect of these combinations on plant growth.

\section{RECOMMENDATION}

From the obtained results it could be recommended to use compost at $150 \mathrm{~g} /$ box (viz. 1.250 $\mathrm{kg} / \mathrm{m}^{2}$ ) on the surface of sandy soil before planting Paspalum vaginatum sods, this treatment caused significant increase in all studied vegetative or root characteristics.

Also using diluted liquid yeast vinasse at any rate from $2 \%$ to $8 \%$ as foliar spray once monthly 
with or without compost addition resulted in significant increase in all studied growth parameters and using vinasse at $6 \%$ as foliar spray resulted in the highest significant increase in most of them.

Moreover, despite the difference of weather conditions at growing period, the effect of addition of compost at $150 \mathrm{~g} /$ box ( viz. $1.250 \mathrm{~kg} / \mathrm{m}^{2}$ ) and diluted yeast vinasse at $6 \%$ as foliar spray was continuous to all studied parameters increased significantly and the highest significant increases was obtained at $28^{\circ} \mathrm{C}$.

\section{REFERENCES}

Awaad MS, Azza RA, Mohamedin AM (2010). Effect of different applied of potassium sources on quantity and quality of groundnut crop grown under newly reclaimed sandy soil conditions. Fayoum J. Agric. Res. \& Dev, 24 (1): 37-48.

Beard JB (1982). Turf management for golf courses. New York: Macmillan, Book

Biswas S Dutta D (2020). Effect of integrated nutrient management (INM) on nutrient uptake, yield and quality of potato (Solanum tuberosum L.) International Journal of Chemical Studies 8(1): 436- 442.

Carter MR, Gregorich EG (2008). Soil sampling and methods of analysis $2^{\text {nd }}$ ed. Taylor \& Francis Group, LLC. U.S.A.

Duncan RR, Carrow RN (2000). Seashore Paspalum -The Enviornmental Turfgrass. John Wiley and Sons Inc., Hobenken, NJ.

Gemtose TA, Chouliaras N, Marakis S (1999). Vinasse rate time of application and compaction effect on soil properties and drum wheat crop. J.Agric. Enging Res. 73 (3) 283-296.

Komdorfer GH, Anderson DL (1993). Use and impact of sugar-alcohol residues vinasse and filter on sugarcane production in Brazil, In Proc. of Inter American Seminor 122. Miami, USA, 15-17 September: 164-170.

Louisa MA, Taguiling G (2013). Quality improvement of organic compost using green biomass. European Scientific Journal December 9 (36): 319341.

Madejon E, L'opez R, Murillo JM, Cabrera F (2001).Agricultural use of three (sugar-beet) vinasse composts: effect on crops and chemical properties of a Cambisol soil in the Guadalquivir river valley ( $\mathrm{SW}$ Spain), Agriculture, Ecosystems and Environment, 84 (1): 55-65.
Mahapatra A, Barik AK, Mishra GC (2018). Integrated nutrient management on babycorn (Zea mays L.). International J. of Bio-resource and Stress Management; 9 (1): 44-48.

Mahmoud SAEH, Siam HS HS, Taaleb AS, ElAshry SM (2019). Significant use of vinasse as a partial replacement with chemical fertilizers sources for spinach and barley production and their effect on growth and nutrients composition of plant. Plant Archives. 19(1):1593-1600.

Martínez JB, Lazcano C, Christensen TH, Muñoz P, Rieradevall J, Møller J, Antón A, Boldrin A (2013). Compost benefits for agriculture evaluated by life cycle assessment. A review. Agron. Sustain. Dev. 33:721-732.

Mo YC, Ye YP, Liang Q, Li YR (2009). "Effects of vinasse on the quality of sugarcane and key enzymes in sucrose synthesis," Southwest China Journal of Agricultural Sciences, 22, (1): 55-59.

Moran $R$ (1982). Formula for determination of chlorophyll pigment extracted with $N, N$ Diethylformamide. Plant Physiol 69(6): 1376-1381.

Nielsen SS (2010). Food Analysis Laboratory Manual $2^{\text {nd }}$ Ed. Springer, New York.

Prado R de M, Caione G, Campos CNS (2013) .Filter cake and vinasse as fertilizers contributing to conser-vation agriculture. Applied Environmental Soil Science 1:1-8.

Raymer P, Braman SK, Burpee LL, Carrow RN, Chen Z, Murphy TR ( 2008). Seashore Paspalum: Breeding a Turfgrass for the Future. Green Section Record. January/February: 22-26.

Snedecor GW, Cochran W (1989). Statistical Methods, Eighth Edition, Iowa State.

Tejada M, Gonzalez JL (2006). Effect of two beet vinasse form on soil physical properties and soil loss. Catena. 68:41-50.

Tennakoon NA, Hemamala Bandara SD (2003). Nutrient Content of Some Locally Available Organic Materials and Their Potential as Alternative Sources of Nutrients for Coconut. http://opendbs.pcarrd.dost.gov.ph/fits /pub db.php. Trenholm LE, Carrow RN, Duncan RR (2001). Wear tolerance, growth, and quality of seashore paspalum in response to nitrogen and potassium. Hort sci. 36(4):780-783. 
Scientific Journal of Agricultural Sciences 2 (2): 19-28, 2020

الملخص العربي

\title{
تأثير فيناس الخميرة على نمو نجيل الباسبالم النامي تحت ظروف استخدام الكمبوست في الاراضي الرملية
}

\author{
أسماء محمد طه \\ قسم بحوث نباتات الزينة بأنطونيادس ـ الإسكندرية ـ معهد بحوث البساتين ـ مركز البحوث الزراعية
}

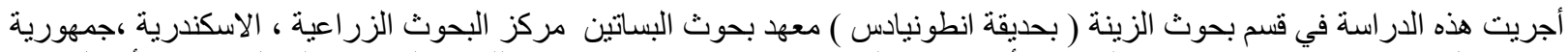

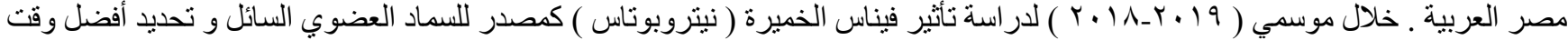

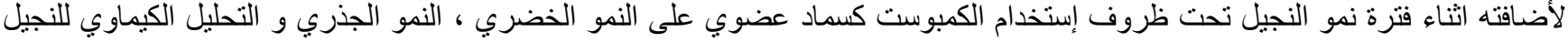

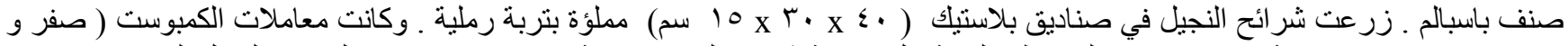

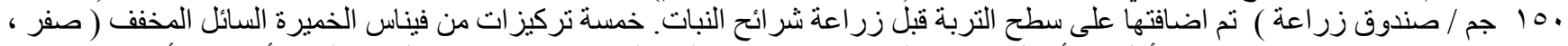

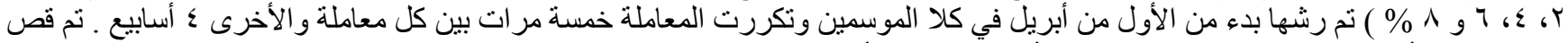

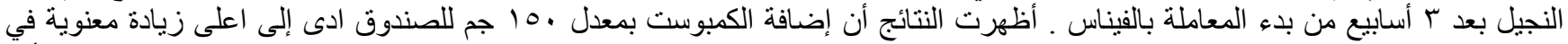

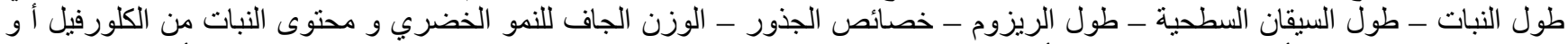

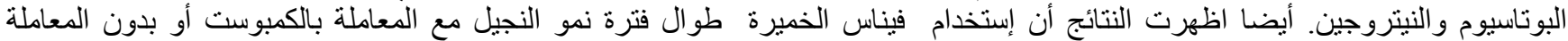

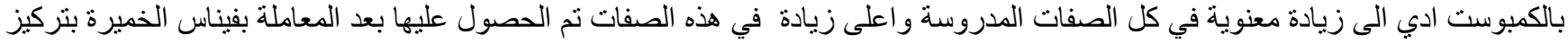

الكلمات الكاثفة : نجيل الباسبالم - فيناس الخمبرة - الكمبوست. 